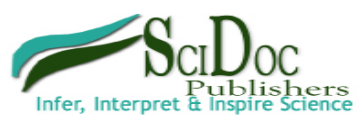

International Journal of Food Science, Nutrition and Dietetics (IJFS)

ISSN 2326-3350

\title{
Biological Inhibition/Toxicity During the Anaerobic Digestion of Wastes From Food And Agricultural Industries
}

Editorial

Rajinikanth Rajagopal

Dairy and Swine research and development Centre, Agriculture and Agri-Food, Canada.

\section{*Corresponding Author:}

Rajinikanth Rajagopal,

Dairy and Swine research and development Centre,

Agriculture and Agri-Food Canada.

E-mail: Rajinikanth.Rajagopal@agr.gc.ca (or) rrajinime@yahoo.co.in

Received: February 26, 2013

Published: April 15, 2013

Citation: Rajagopal R (2013) Biological Inhibition/Toxicity During the Anaerobic Digestion of Wastes From Food And Agricultural Industries. Int J Food Sci Nutr Diet. 2(1e), 1-2. doi: http://dx.doi. org $/ 10.19070 / 2326-3350-130001 \mathrm{e}$

Copyright:Rajagopal R ${ }^{\circ} 2013$. This is an open-access article distributed under the terms of the Creative Commons Attribution License, which permits unrestricted use, distribution and reproduction in any medium, provided the original author and source are credited.

With agricultural crops, the land is ploughed in preparation for crop planting, fertilizers and pesticides are employed, and the crops are harvested and stored before processing into consumer products. With animal farming, livestock and poultry are raised and sent to slaughterhouses. Food and agricultural industries yield either consumer products directly or associated materials that are then used to produce such products such as leather or cotton [1]. In producing such consumer items, almost all the processes and stages, from crop planting or animal rising to the processing into end products, lead to numerous pollution problems which includes deterioration of air, water and land quality. For instance, wastewater produced from many of the food and agricultural industries are hazard to the environment and require apt comprehensive management approach. The environmental regulatory authorities in North America, elsewhere in the world, are setting stringent norms for discharging waste pollutants (both liquid and solid) from such industries. To accomplish the regulations for the discharge limits, there is now an alarming need to treat and utilize these wastes rapidly and efficiently. With the remarkable pace of advancement of sustainable environmental biotechnology, extensive research has been dedicated recently to cope with wastes of ever increasing complexity generated by the food and agricultural industries. Bioenergy production from anaerobic digestion (AD) of organic wastes is a promising climate change mitigation option and considered as a sustainable treatment technology. Nowadays, the carbon emission and as a result, carbon footprint of water utilities is an important concern worldwide. In this perception, it is crucial to consider the prospects for the reduction of carbon footprint from small and large wastewater treatment plants. Not only does the anaerobic digestion technology has an affirmative net energy production but the biogas produced can also replace fossil fuel, therefore, has a direct positive effect on greenhouse gas reduction.
Despite these valuable advantages, anaerobic digesters treating highly concentrated wastes, such as food and concentrated animal/livestock manure, are likely to suffer from partial or complete inhibition of methaneproducing consortia, including methanogens [2,3]. A variety of inorganic and organic wastes can cause toxicity in anaerobic digesters. Toxicity due to sodium is a common problem causing inhibition of anaerobic digestion. Zhao et al. [4] confirmed that organofluorine compounds such as 4-fluorophenol (p-FP), 4-fluorobenzoic acid ( $\mathrm{p}-\mathrm{FB}$ ) and 4-fluoroaniline (p- FA) have a potential toxicity on methanogenesis and Rajinikanth Rajagopal, International Journal of Food Science, Nutrition and Dietetics 2013, 2:301 2 biodegradability. High concentrations of volatile fatty acids (VFAs) are often associated with the effects of toxicity and inhibition. VFA inhibitions can occur due to their accumulation and a subsequent reduction in $\mathrm{pH}$ value. Depending on $\mathrm{pH}$ values, VFA concentrations can be tolerated with a minimal degree of toxicity. Nevertheless, at low $\mathrm{pH}$, much more of the VFAs exists in the undissociated form which is much more toxic than ion form, due to its greater membrane permeability. Procházka et al. [5] described that high ammonia nitrogen concentration [especially the unionized form] $(4.0 \mathrm{~g} / \mathrm{L})$ would inhibit methane production, while low ammonia nitrogen concentration $(0.5 \mathrm{~g} / \mathrm{L})$ could cause low methane yield, loss of biomass and henceforth the loss of aceticlastic methanogenic activity. Chen et al. [6] indicated that certain ions such as $\mathrm{Na}^{+}, \mathrm{Ca}^{2+}$, and $\mathrm{Mg}^{2+}$ were found to be antagonistic to ammonia inhibition, a phenomenon in which the toxicity of one ion is decreased by the presence of other ion(s). At high concentrations, potassium, light metals ions $(\mathrm{Na}, \mathrm{K}, \mathrm{Mg}, \mathrm{Ca}$, and $\mathrm{Al}$ ) and other salts can also interrupt cell function [6].

Several researchers have attempted to come up with toxicity control strategies. Vyrides et al. [7] indicated that glycine-betaine, an organic compound, which can cause antagonism against sodium toxicity. However, using glycine-betaine to decrease sodium toxicity in commercial scale anaerobic digesters would be too costly [2]. Suwannoppadol et al. [2] described that when grass clippings were added at the onset of $\mathrm{AD}$ of acetate containing a sodium concentration of $7.8 \mathrm{~g} \mathrm{Na}+/ \mathrm{L}$, a total methane production about $8 \mathrm{~L} \mathrm{CH} 4 / \mathrm{L}$ was obtained, whereas no methane was produced in the absence of grass leaves. Another way of tackling the sodium salts problem is by allowing the anaerobic sludge to acclimate to high sodium concentrations [8] but this technique requires time for the methanogens to adapt to the saline conditions which in turn results in a prolonged period before the anaerobic reactor can achieve its full-loading capacity. Zhao et al. [4] suggested that adsorption was the main removal mechanism for the three F-substituent aromatics such as 4-fluorophenol (p-FP), 4-fluorobenzoic acid ( $p-F B)$ and 4-fluoroaniline (p-FA). To tackle with ammonia toxicity many strategies have been attempted: chemical precipitation, $\mathrm{pH}$ and temperature control [6]; use of carbon fiber textiles 
[9] ammonia stripping and adjustment of $\mathrm{C}: \mathrm{N}$ ratio of feedstock [10]; acclimation of methanogenic consortia to high levels of ammonia [11]. Uludag-Demirer et al. [12] and Wang et al. [13] described the physical, chemical, and biological methods, such as addition of ammonium-selective adsorbent, ammonium removal by forming struvite precipitation, or biological anoxic/oxic (A/O) process. Among these methods, ammonium removal by adding ammonium-selective adsorbents could be the most attractive and practical because of its easier operation and economic, and the ammonium-saturated adsorbents can be further used as nitrogen fertilizer [13]. In many circumstances, acclimation of digester with cations can often increase the toxicity threshold limit.

Although, substantial amount of literature on this subject, inhibition due to sodium, high VFAs, sulphides, ammonia, aforesaid ions etc., are still an everyday threat at AD (biogas) plants performing co-digestion and process imbalances caused by these toxic agents is often reported. Cautious substrate management and early detection of inhibitions is, of cause, crucial in order to minimize the economic losses.

\section{References}

[1]. http://www.epa.gov/ttnchie1/ap42/ch09/index.html

[2]. 2. Suwannoppadol, S.; Ho, G.; Cord-Ruwisch, R. Overcoming sodium toxicity by utilizing grass leaves as co-substrate during the startup of batch thermophilic anaerobic digestion. Bioresour. Technol. 2012, 125, 188-192.

[3]. 3. Hierholtzer, A.; Akunna, J.C. Modelling sodium inhibition on the anaero- bic digestion process. Wat. Sci. Technol. 2012, 66, 1565-1573.

[4]. 4. Zhao, Z-Q.; Xu, L-L.; Li, W-B.; Wang, M-Z.; Shen, X-L.; Mae, G-S.; Shena, D.-S.Toxicity of three F-substituent aromatics in anaerobic systems. J. Chem. Technol. Biotechnol. 2012, 87, 1489-1496.

[5]. 5. Procházka, J.; Dolejš, P.; Máca, J.; Dohányos, M. Stability and inhibition of anaerobic processes caused by insufficiency or excess of ammonia nitrogen. Appl. Microbiol. Biotechnol. 2012, 93, 439-447.

[6]. 6. Chen, Y.; Cheng, J.J.; Creamer, K.S. Inhibition of anaerobic digestion process: a review. Bioresour. Technol. 2008, 99, 4044-4064.

[7]. 7. Vyrides, I.; Santos, H.; Mingote, A.; Ray, M.J.; Stuckey, D.C. Are compatible solutes compatible with biological treatment of saline wastewater? Batch and continuous studies using submerged anaerobic membrane bioreactors (SAMBRs). Environ. Sci. Technol. 2010, 44, 7437-7442.

[8]. 8. Vyrides, I.; Stuckey, D.C. Adaptation of anaerobic biomass to saline conditions: role of compatible solutes and extracellular polysaccharides. Enzyme Microb. Technol. 2009, 44, 46-51.

[9]. 9. Sasaki, K.; Morita, M.; Hirano, S.; Ohmura, N.; Igarashi, Y. Decreasing ammonia inhibition in thermophilic methanogenic bioreactors using carbon fiber textiles. Appl. Microbiol. Biotechnol. 2011, 90, 1555-1561

[10]. 10. Resch, C.; Wörl, A.; Waltenberger, R.; Braun, R.; Kirchmayr, R. Enhancement options for the utilisation of nitrogen rich animal by-products in anaerobic digestion. Bioresour. Technol. 2011, 102, 2503-2510.

[11]. 11. Abouelenien, F.; Nakashimada, Y.; Nishio, N. Dry mesophilic fermentation of chicken manure for production of methane by repeated batch culture. J. Biosci. Bioeng. 2009, 107, 293-295.

[12]. 12. Uludag-Demirer, S.; Demirer, G.N.; Frear, C.; Chen, S., Anaerobic digestion of dairy manure with enhanced ammonia removal. J. Environ. Manage. 2008, 86, 193-200.

[13]. 13. Wang, Q.; Yang, Y.; Li, D.; Feng, C.; Zhang, Z. Treatment of ammonium-rich swine waste in modified porphyritic andesite fixed-bed anaerobic bioreactor. Bioresour. Technol. 2012, 111, 70-75. 